Larry M. Hyman : The Role of Borrowing in the Justification of Phonological Grammars William E. Welmers: The Derivation of Igbo Verb Bases

Herbert Stahlke: Serial Verbs

Isaac George : Nupe Tonology

Subscription per volume ( 3 issues); $\$ 6.00$ U.S. and Canada, $\$ 7.00$ other. Single issues are available at $\$ 2.50$ each. Cheques should be made payable to African Studies Center, UCLA; orders and articles for publication should be sent to The Editor, Studies in African Linguistics, c/o Department of Linguistics, University of California, Los Angeles, California 90024.

\title{
Le Cercle d'Anthropologie de l'Institut National des Sciences Appliquées de l'Univer- sité de Lyons
}

LE Cercle propose à ses membres et au public une présentation des Sciences Humaines par l'intermédiaire de cours, conférences où sont conviés des spécialistes, seminars, et nombreux films à caractère ethnologique. Ils préparent pour l'été I 970 un voyage ('study-visits ') en Afrique Occidentale. Cette expédition est facilitée par un premier voyage, effectué en juillet-aôut 1969 , au Sénégal.

\section{A Bibliography of Anthropological Bibliographies: Africa}

This bibliography, compiled under the direction of Dr. Gordon D. Gibson, published in Current Anthropology, vol. ro, no. 5, December 1969, pp. 527-66, covers ethnology and ethnography, social anthropology, culture history, historic archaeology, prehistory, folklore, linguistics, race, and ancient man, with all the common subdivisions of these disciplines, and extends into the neighbouring fields of history, sociology, psychology, economics, political science, education, human geography, and medicine. The items are arranged topically and geographically and there is an index of authors and subjects designed for quick reference to major listings.

\section{Treize cartes historiques d'Afrique occidentale (Sénégal et Haut-Sénégal-Niger) I 802- 1899}

Extraites du fond des Archives nationales d'Outre-Mer (Paris), certaines d'entre elles sont manuscrites et ont été dressées lors de la conquête du Soudan; y figurent en particulier la toponymie et le découpage de ces régions au XIX ${ }^{e m e}$ siècle. Présentation de $\mathrm{M}$. C. Meillassoux.

En vente à la Société des Africanistes, Musée de l'Homme, place du Trocadéro, Paris 16 $6^{\ominus}$. Prix de vente: 35 Fr.

\section{French and Francophone Institutions Engaged in African Studies}

WE have received the following addition and amendment to the list given in Africa, xl, i, January 1970, pp. 71-5. It should be noted that this covered only French and related institutions in Tropical Africa. It did not include Francophone institutions in North Africa or in Congo (Kinshasa) or in French-speaking Canada.

Togo: Institut Supérieur du Bénin, Lomé (Director, J. S. Santoni); publishes Bulletin de l'Enseignement Supérieur du Bénin.

Société pour l'Étude des Langues Africaines (SELAF), Bibliothèque de la SELAF, publication trimestrielle, 5, rue de Marseille, 75-Paris 10 (Secretary, Jacqueline M. C. Thomas, Maître de Recherche, au CNRS). 